This is a peer-reviewed, accepted author manuscript of the following research article: Kenny, M., Gillies, L., \& James, D. (2012). The EU optional instrument: absorbing the private international law implications of a common European sales law. In A. Bonomi, \& G.

P. Romano (Eds.), Yearbook of Private International Law 2011 (Vol. 13, pp. 315-344). Sellier.

\title{
THE EU OPTIONAL INSTRUMENT: ABSORBING THE PRIVATE INTERNATIONAL LAW IMPLICATIONS OF A COMMON EUROPEAN SALES LAW
}

\author{
Mel KENNY* / Lorna GILLIES ${ }^{* *} /$ James DEVENNEY***
}

I. Introduction

II. Consolidation of Europeanised Private Law: Questioning the Rationale
A. Coherence in EU Private Law (1): Europeanization and Interlegality
B. Coherence in EU Private Law (2): Fragmentation and Polycentricity
C. Questioning the Rationale for EU Private Law Consolidation

III. Evolution of the (D)CFR/Consolidation Initiative
A. The 2001 Communication on European Contract Law
B. The 2003 Action Plan
C. The 2004 Communication
1. Evaluation of the 2004 Communication
D. Commission's 2007 Green Paper on the Consumer Acquis
E. The (D)CFR
F. The (Proposed) Common European Sales Law

IV. Reflections on the (Proposed) Common European Sales Law
A. Fragmentation
B. Consistency of Interpretation
C. Application of Rules
D. Consumer Protection and Enforcement

V. Private International Dimensions to the CESL
A. The CESL: An Optional Set of National Contract Law Rules
B. The CESL, and the Rome I Regulation: Business to Business Contracts 1. Article 3: Freedom of Choice 2. Scope of CESL: An Improved Option for Businesses?
C. Interaction with Article 4: Applicable Law in the Absence of Choice
D. The CESL and the Rome I Regulation: Business-to-Consumer Contracts
E. What Does the Proposal Say Regarding Validity, Consent and Illegality? Kingdom.

* Professor of Consumer and Commercial Law, De Montfort Law School, United

** Senior Lecturer in Commercial Law, Leicester Law School, United Kingdom.

*** Professor of Commercial Law, Exeter Law School, United Kingdom.

Yearbook of Private International Law, Volume 13 (2011), pp. 93-106 (C) sellier. european law publishers \& Swiss Institute of Comparative Law Printed in Germany 
F. Underlying Choice of Law Issues to Be Resolved

VI. Closing Remark

\section{Introduction}

This paper explores the process of the "Europeanization" of national Private Law regimes in the European Union from its antecedents in the internal market programme to the current proposals surrounding the (Draft) Common Frame of Reference ((D)CFR) and a Common European Sales Law. The paper begins by critically evaluating the rationale behind the consolidation/codification initiative, the evolution of the initiative and then drills into the broader implications of this process; considering, in particular, the Private International Law dimensions to the proposed (optional) Common European Sales Law (CESL). In this analysis we therefore enter a polycentric legal environment traversing Contract Law, Consumer Law, EU Law and Private International Law.

\section{Consolidation of Europeanised Private Law: Questioning the Rationale}

\section{A. Coherence in EU Private Law (1): Europeanization and Interlegality}

The intervention of EU secondary law in Member States' Private Law systems has led to the increasing "Europeanization" of Private Law and the emergence of a new body of "EU Private Law" (Gemeinschaftsprivatrecht). ${ }^{1}$ This new body of law has proved unstable: sector-specific, "vertical" EU legislation combining with divergent national transpositions and judicial interpretations. Yet precisely this instability has strengthened the case for further consolidation of EU private law; to the distilling of a single, coherent ius commune. ${ }^{2}$ Yet whilst few would question the constant need to improve legislation, or for greater transparency in national transposition practice, or for enhanced judicial collaboration, the elaboration of an EU Civil Code would be much more controversial, going beyond the enumerated powers of the EU. ${ }^{3}$

1 R. Brownsword/ H-W. Micklitz/ L. Niglia/ S. Weatherill (eds), The Foundations of European Private Law, Oxford 2012; P.-C. Müller-GrafF (ed.), Gemeinsames Privatrecht in der Europäischen Gemeinschaft, Baden-Baden 1999; B. HeIDERHOFF, Gemeinschaftsprivatrecht, München 2005. See "Common Core of European Private law" Series, (M. Bussani/ U. MAtTeI, et al. (eds)), Cambridge University Press: $<$ www.cambridge.org $>$ ). Similarly Ius Commune Casebooks, (Hart Publishing: $<$ www.hartpub.co.uk $>$ ).

${ }^{2}$ C. vON BAR, From Principles to Codification: Prospects for European Private Law, [2002] 8 Colum. J. Eur. L. 379; O. LANDO, Does the European Union need a Civil Code, [2003] RIW 1.

${ }^{3}$ S. Weatherill, Why Object to the Harmonisation of Private Law by the EC, (2004) 12 E.R.P.L. 636 . 
That national systems of Private Law would be influenced by European law was always clear given the goal of market integration central to the European Project. Indeed, the EU has always instrumentalised private (in particular contract) law as a simple means to complex policy ends: to achieve goals in competition, free movement, consumer protection, public procurement and non-discrimination. The law which emerged from this process is a functional rather than systematic body of law; developed piecemeal to solve problems, rather than holistically to ensure coherence. ${ }^{4}$ Indeed, initially, it was hoped that EC Law would simply erode market-partitioning national laws through application of the four freedoms, a competition of legal orders and a judicially initiated programme of negative integration. ${ }^{5}$ Set to this diverse background the case for greater coherence in EU Private Law appears vital.

The Europeanization of national Private Law can be linked to Weiler's model of the Transformation of Europe, ${ }^{6}$ a process beginning in earnest in the 1980s with the advent of the Internal Market. ${ }^{7}$ Directly in Consumer Protection and Company law and indirectly, through block exemptions in competition law ${ }^{8}$ and in the EU policy fields, ${ }^{9}$ national Private Law was increasingly shaped by EU Law. Yet outside the fields of EU competence, national laws continued to apply, and national demarcations within the law, for example, between Contract and Tort, Contract and Property, held their divergent validities. The Europeanization of Private Law is therefore an aspect of what de Sousa Santos termed interlegality, of an intersection of legal orders. ${ }^{10}$

\section{B. Coherence in EU Private Law (2): Fragmentation and Polycentricity}

Yet even where EU secondary law was passed "uniform" legal solutions were rare such that legal fragmentation has always accompanied EU harmonisation. Thus, whilst regulations frequently failed to unify the law due to bartering in the lawmaking process, directives regularly established transposition frameworks, which

${ }^{4}$ N. REICH, A Common Frame of Reference (CFR)-Ghost or Host for Integration?, (2006) 24 Wis. Int'l Law J. 425.

${ }^{5}$ W. SAUTER, The Economic Constitution of the EU, [1998] 4 Colum. J. Eur. L. 27; D.J. GERBER, Constitutionalizing the Economy: German Neo-liberalism, Competition law and the "New" Europe, [1994] 42 Am. J. Comp. L. 25; N. REICH, Europe's Economic Constitution, or: A New Look at Keck, [1999] O.J.L.S. 337.

${ }^{6}$ J.H.H. WeILER, The Transformation of Europe, (1991) 100 Yale L. J. 2403. ment) Act 1986

${ }^{7}$ Single European Act, [1987] OJ L 169/1; UK: European Communities (Amend-

${ }^{8}$ Inter alia Commission Regulation 330/2010 on the application of Article 101(3)

TFEU to categories of vertical agreements and concerted practices, [2010] OJ L 102/1.

${ }_{9}$ EU Policy fields: Public Health: Art. 168 TFEU; Environment: Arts. 191-193

TFEU; Employment: Title IX TFEU; Industrial Policy: Art.173 TFEC; Economic and Social Cohesion: Title XVIII TFEU; R\&D: Title XIX TFEU. G. BrÜgGemeIER/ C. Joerges, Europäisierung des Vertragsrechts und Haftungsrechts, in P.-C. MüLLER-GRAFF (note 1), at 312-313.

${ }^{10}$ B. De Sousa Santos, Law: A Map of Misreading. Towards a Post-Modern Conception of Law, [1987] J.L.S. 279, at 298. 
laid down standards, which Member States could exceed through measures of upward derogation. ${ }^{11}$ Different Commission approaches to the drafting of secondary law (EU level) and divergent national transposition practice (national level) led to further fragmentation; generating inconsistencies throughout EU secondary law and its transposition in national laws. Moreover, fragmentation in its international dimension was exacerbated by the communitarisation of aspects of procedural law thereby "disengaging" Member States from the Formulating Agencies' initiatives. ${ }^{12}$ Simultaneously, lex mercatoria contracting and arbitration, perceived as methods by which parties could emancipate themselves from national law, were becoming more common. This combination of factors means that polycentricity dominates in cross-border trade; a plethora of non-national legal sources, whether EU law, lex mercatoria, the CISG rules, the UNIDROIT Principles of International Commercial Contracts ("UNIDROIT Principles" 2004) or the 1980 EC Rome Convention so became important sources of Private Law.

Given this fragmentation and polycentricity it is unsurprising that calls for the codification of EU Private Law became popular and also that the ius commune project became flanked by initiatives aimed at simplifying and improving the regulatory environment. ${ }^{13}$ Simultaneously, however, the realisation grew that, just as harmonisation had led to fragmentation, so too could codification: that the choice made between liberalisation and regulation always lends the law more of a "patchwork" than a "uniform" quality. Finally, with intensifying regulatory competition the case-law driven phenomenon of "spontaneous" harmonisation became more common and further eroded the case for broader codification. ${ }^{14}$

\section{Questioning the Rationale for EU Private Law Consolidation}

The rationale for the (D)CFR initiative has always been connected with ensuring the coherence of EU Law. Yet far from creating a consistent body of Consumer Law EU harmonisation has led to the emergence of 27 national rules on doorstep selling, distance selling, timeshares, package holidays, consumer credit and in each other area governed by a relevant secondary law provision. ${ }^{15}$ Yet while we may

11 Via minimum harmonisation: Art. 114(4) TFEU; See also: Art. 193 TFEU; Art. 169(5) TFEU.

${ }^{12}$ B. HEß, Die Integrationsfunktion des Europäischen Zivilverfahrensrechts, [2001] IPRax 389, at 395.

${ }^{13}$ European Governance-A White Paper (COM(2001) 428 final), [2001] OJ C 287/1. SLIM Initiative (Simpler Legislation for the Internal Market): (COM(1996) 204 final); Review of SLIM (COM(2000) 104 final); Simplifying and improving the regulatory environment (COM(2001) 726 final); European governance -A white paper, [2001] OJ C $287 / 1$

${ }^{14}$ A.I. Ogus, Competition between National Legal Systems: a Contribution of Economic Analysis to Comparative law, [1999] I.C.L.Q. 405; E. KIENINGER, Wettbewerb der Privatrechtsordnungen im Europäischen Binnenmarkt, Tübingen 2002; N. REICH, Competition of Legal Orders-A new Paradigm of EC law?, [1992] 29 C.M.L.Rev. 861.

${ }^{15}$ C. Twigg-Flesner, Good-Bye Harmonisation by Directives, Hello Cross-Border only Regulation? A way forward for EU Consumer Contract law, (2011) 7 E.R.C.L. 235, at 241 
acknowledge the importance of the motive of "greater coherence", the full implications of chasing such an elusive concept remain to be developed. Private lawyers are thus drawn into a critical examination of the coherence of EU law. This paradigm relies on the forms of action: direct actions (Articles 258 \& 259 TFEU); judicial review (Article 263 TFEU); preliminary references (Article 267 TFEU); actions for non-contractual institutional liability (Art. 340 TFEU). Yet the paradigm also relies on the tangible effects of EU law: the doctrines of Direct Effect and Supremacy; the specific effects of directives; ${ }^{16}$ and the doctrine of State liability. In theory, this combination produced a comprehensive regime for ensuring the coherence of EU Law, as famously asserted in UPA:

“...[T]he Treaty has established a complete system of legal remedies and procedures designed to ensure judicial review of the legality of acts of the institutions, and has entrusted such review to the Community courts. ...(W)here natural or legal persons cannot... directly challenge (EU) measures... they are able... either indirectly to plead the invalidity of such acts... or to... ask (national courts)(...) to make a reference..."

Within the "completeness" of this paradigm the CJEU's (ex ECJ) role is to ensure the uniform application of EU Law. ${ }^{18}$ But the coherence of EU Law has to be appreciated as part of the broader issue of compliance. ${ }^{19}$ This uncovers a perennial governance problem, especially acute in a system of indirect administration such as in the EU in which policies are implemented decentrally by national executive and judicial authorities enjoying margins of discretion..$^{20} \mathrm{~A}$ wider understanding of coherence is therefore required: coherence as a product of judicial and administrative initiatives.

Inevitably, the importance attached to Article 267 TFEU meant that the coherence of EU Law was doubly compromised: by reliance on litigation and the variation in national legal remedies. As Snyder observes, judicial effectiveness is therefore: "...less normatively coherent and less comprehensive than a legislative scheme... (Furthermore) (d)ifferences in national remedies affect the extent to which individuals can rely... on rights derived from Community law..." ${ }^{21}$ Finally, the "incompleteness" of EU Law is buttressed by the basic characteristics of EU Law: subsidiarity; national margins of discretion in implementation and judicial procedural autonomy; the attributed competences of the EU ${ }^{22}$; the margins of direct and individual concern under Article 263 TFEU; the margins of State liability

${ }^{16}$ P. CRAIG/ G. DE BÚRCA, EU LAW, $4^{\text {th }}$ ed., OUP, 2008, at 279-300.

${ }^{17}$ Case C-50/00 P, Unión de Pequeños Agricultores v Council (UPA), [2002] ECR I6677, para. 40.

${ }^{18}$ F. MANCINI, The Making of a Constitution for Europe, (1989) 26 C.M.L.Rev. 595, at 606: the national legal order reliant on the ECJ's "unlimited patience".

19 F. SNYDER, The Effectiveness of European Community Law: Institutions, Processes and Techniques, (1993) 56(1) M.L.R. 19, at 19-20.

${ }^{20} \mathrm{Ibid}$., at 22.

${ }^{21}$ Ibid., at 51 .

${ }^{22}$ Articles 2(5), 169 \& 114 TFEU. 
under Article $267 \mathrm{TFEU}^{23}$; Commission discretion to take action under Article 258 TFEU.

\section{Evolution of the (D)CFR/Consolidation Initiative}

Set against the uncertain rationale for greater coherence, this paper now turns to mapping the evolution of the (D)CFR initiative.

\section{A. The 2001 Communication on European Contract Law}

The 2001 Communication $^{24}$ drew particular attention to the divergent transposition and uneven operation of EC Contract Law. The Commission sought to initiate debate on the need for a consolidation of the contract relevant aspects of secondary law along the lines of four options:

- Option I: not to intervene but to rely on a competition of legal orders;

- Option II: to elaborate non-binding principles based on the Lando or UNIDROIT principles;

- Option III: to undertake a general evaluation, improvement and consolidation of existing instruments;

- Option IV: to introduce (a) new legal instrument(s), into which contracting parties could either opt-in or opt-out, to consolidate the law.

The range of options was criticised: opening a discussion on consolidation with a non-intervention option arguably revealing the Commission's result-orientation.

\section{B. The 2003 Action Plan}

Unsurprisingly, the 2003 Action Plan $^{25}$ rejected the 2001 Communication's nonintervention option and approved Options II-IV; distilling three areas in which further initiatives were required:

- The Common Frame of Reference (CFR). The CFR was to strengthen the quality of the acquis: tackling divergent transpositions and providing guidance to questions of interpretation. ${ }^{26} \mathrm{~A}$ need was also identified for an overhaul of funda-

\footnotetext{
${ }^{23}$ Case C-224/01, Köbler v Austria, [2003] ECR I-10239; Case C-173/03, Traghetti del Mediterraneo v Italy, [2006] ECR I-5177. $255 / 1$.

${ }^{24}$ Communication on European Contract Law (COM(2001) 398 final), [2001] OJ C

25 Communication on a More Coherent Contract Law - An Action Plan, (COM(2003) 68 final.), [2003] OJ C 63/1; D. Staudenmayer, The Commission Action Plan on European Contract Law, [2003] 2 E.R.P.L. 113.

${ }^{26}$ Case C-168/00, Simone Leitner v TUI Deutschland GmbH \& Co. KG, [2002] ECR I-2631.
}

$98 \quad$ Yearbook of Private International Law, Volume 13 (2011) 
mental concepts (conclusion and validity of contracts, non-performance and unjust enrichment, representation of foreign companies, formal demands and the exclusion or limitation of liability ${ }^{27}$ and to identify areas requiring special treatment (financial and insurance services, transfer and reservation of title, cabotage transport, factoring, consumer protection and tort law).$^{28}$

- EC-wide standard contract terms and conditions. The Commission aiming to facilitate the exchange of information on the utility of standardised contract terms and conditions. ${ }^{29}$

- The opportuneness of new optional instrument(s). In launching an assessment of the need for new optional instrument(s) the Commission sought to supply a measure of horizontal coherence to "EC Contract Law". Guidelines for the elaboration of these measures were mapped out. ${ }^{30}$

The 2003 Action Plan appeared to contradict itself: retaining the sector-specific approach, whilst underplaying the horizontal implications of its analysis though a questioning of the opportuneness of the horizontal optional instrument(s). ${ }^{31}$ Furthermore, some questions were not addressed: on the form of the optional instrument(s); on the relationship between CFR and the optional instrument(s)); on the choice of law; on the proportionality and legitimacy of the reforms. Similarly, questions on the availability of the standard terms and conditions in purely "internal", i.e. national, transactions were left unresolved. ${ }^{32}$ Some of this can be explained: given the controversy surrounding the idea of a European Civil Code, the project had to be marketed "neutrally". In this vein, recalling the restrictions placed in Tobacco Advertising, the Commission was hardly likely to begin with an examination of the appropriate legal base. ${ }^{33}$ Equally the Commission's strategy can be explained in that policy inertia works to its advantage; the longer the consultative period, the more emphatic the case for reform becomes.

\section{The 2004 Communication}

A new circumspection emerged following the 2003 Action Plan. In this vein BASEDOW appealed for gradualism: to first develop the CFR as a basis for opt-in, sector-specific instruments, to convert these into opt-out instruments, and, over 2030 years, to extend these instruments horizontally. ${ }^{34}$ The 2004 Communication also appeared to subscribe to gradualism, setting a three-year (2005-2007) research

\footnotetext{
${ }^{27} 2003$ Action Plan (note 25), at paras 32, 33, 34, 35-36.

${ }^{28}$ Ibid., paras 30-31, 47-48, 41-42, 43, 49-50, and 67.

${ }^{29} \mathrm{Ibid}$., paras $81-88$ at 21-23.

${ }^{30} \mathrm{Ibid}$., paras 89-97 at 23-24.

${ }^{31}$ M. Kenny, The 2003 Action Plan on European Contract Law: is the Commission Running Wild?, [2003] 28 E.L.Rev. 538.

322003 Action Plan (note 25), at 21-23.

${ }^{33}$ Case C-376/98, Germany v Parliament and Council (Tobacco Advertising), [2000] ECR I-8419, paras 83 and 84.

${ }^{34}$ J. BASEDOW, Ein optimales Europäisches Vertragsgesetz - opt-in, opt-out, wozu überhaupt?, [2004] 12 ZEuP 1, at 4.
} 
phase to prepare the CFR, ${ }^{35}$ following which a drafting stage was to be initiated (2008-2009), allowing for CFR adoption by 2009. The 2004 Communication also elaborated on the possible Principles of European Contract Law ("PECL")-based structure of the CFR. ${ }^{36}$ Meanwhile Annex II to the 2004 Communication set out the parameters of the opportuneness of the optional instrument. The main points can be summarised:

- The CFR was central to the Communication, ${ }^{37}$ its main role being to improve the acquis through uniform definitions of legal terms, fundamental principles and model contract law. ${ }^{38}$ The CFR was to test the coherence of EU secondary law, and, where appropriate, to simplify or codify the relevant sectoral framework. In surveying the consumer acquis, ${ }^{39}$ the 2004 Communication stressed the need to combat differences deriving from the patchwork of secondary law and from national measures of upward derogation. The Commission also identified insurance contracts, contracts of sale and services, clauses relating to the retention and transfer of title and late payments as areas in which sector-specific solutions were required. ${ }^{40}$ Surprisingly, on demarcation, the Commission concluded that "there are no appreciable problems arising from the differences in the interaction between contract law and tort law...". ${ }^{41}$ The Commission foresaw that the CFR was, initially, to adopt the form of a non-binding instrument.

- EC-wide standard terms and conditions: an intention to promote the simplification of cross-border trade was confirmed. The Commission aimed to establish a platform for the information on EU-wide standard terms and conditions supplying guidelines on their relationship to the competition rules and identifying obstacles to their use. ${ }^{42}$

- The optional instrument. The 2004 Communication advocated a single optional instrument, acknowledging that it would operate horizontally.

${ }^{35} 2004$ Communication on European contract law and the revision of the Acquis: the way forward, $\operatorname{COM}(2004) 651$ final. October 11, 2004, [2005] OJ C 14/6, at 13. Contract law.

${ }^{36} \mathrm{Ibid}$., Annex I, at 14-16, lends the CFR the structure of the Principles of European

${ }^{37}$ Ibid., 2-5 functions and legal nature; 9-13 preparation and elaboration; 14-16 (Annex I) structure.

${ }^{38}$ Ibid., Section 2.1.1., at 3; Section 3.1.3.

39 Ibid., at 3-4. Desirability of Codification given the interplay of Consumer directives: Directive 85/577 on doorstep selling, [1985] OJ L 372/31; Directive 90/314 on package travel and holiday tours, [1990] OJ L 158/159; Directive 94/47 the Timeshare Directive, [1994] OJ L 280/83; Directive 97/7 on distance selling, [1997] OJ L 144/19; Directive $98 / 6$ on consumer protection in the indication of the prices of products offered to consumers, [1998] OJ L 80/27; Directive 98/27 on injunctions for the protection of consumer interests, [1998] OJ L 166/51; and Directive 1999/44 on certain aspects of the sale of consumer goods and associated services, [1999] OJ L 171/12.
${ }^{40}$ Ibid., at 9.
${ }^{41}$ Ibid., at 11.
${ }^{42}$ Ibid., at 6-8. 
The EU Optional Instrument on a Common European Sales Law

\section{Evaluation of the 2004 Communication}

That the "non-Code" was to be developed by the Study Group, indeed the Study Group's dominance in this discourse, confirms a central paradox of this initiative. ${ }^{43}$ As regards the sector-specificity of the proposals, ${ }^{44}$ this appeared compromised; the Communication bypassing the legal base question as if it possessed a general "residual" competence. Necessarily, the need to resolve demarcational issues (between Contract, Property and Tort) as they arise between national legal orders extended the project into general Private Law. ${ }^{45}$ Furthermore, the commitment to a single optional instrument confirmed the initiative's horizontal impact. Meanwhile, rather than the analytical starting point, the legal base issue was relegated to the last point of Annex II. ${ }^{46}$ Meanwhile, whilst many features remained unspecified (e.g. whether opt-in or opt-out, whether applicable to domestic situations) other options (i.e. differentiated integration) were ignored. Moreover, any codificatory measures as might emerge would in any case not obviate the need to juridify the remaining patchwork of Private Law norms: a Common Law turn, would inevitably assume greater importance. As AMSTUTZ anticipated, this would lead to everdeeper rearrangements in the Civilian approach. ${ }^{47}$ Equally, as FARNSWORTH observed, this would also lead to a rearrangement of the Common Law approach to EC Private Law. ${ }^{48}$ Finally, as far as proportionality was concerned the fundamental question remained of whether it was not more pragmatic to ensure a basic framework for judicial cross-border co-operation. ${ }^{49}$ The important caveat such

${ }^{43}$ Inter alia: C. VON BAR/ U. DROBNIG, The Interaction of Contract Law and Tort and Property Law in Europe, Munich 2004; W. VAN GeRven/ J. LeVer/ P. LAROUCHE (eds), Cases, Materials and Text on National and International Tort Law, Oxford 2000; R. Schulze/ A. Engel/ J. Jones (eds), Casebook Europäisches Privatrecht, Baden-Baden 1999; Critically: K. RIEDL, The Work of the Lando-Commission from an Alternative Viewpoint, [2000] 8 E.R.P.L. 71. Other approaches: Trento Group on the Common Core of European Contract: <www.jus.unitn.it/elsg >; Society of European Contract Law ("SECOLA"): $<$ www.secola.org >; European Research Group on Existing EC Private Law (Acquis Group): <www.acquisgroup. org >; European Private law Forum: <www.iue.it >; W. Wurmnest, Common Core, Grundregeln, Kodifikationsentwürfe, Acquis-GrundsätzeAnsätze internationaler Wissenschaftlergruppen zur Privatrechtsvereinheitlichung in Europa, [2003] 11 ZEuP 714.

${ }^{44}$ Ex Art. 7(1) EC: "Each institution shall act within the limits of the powers conferred upon it by this Treaty". Functional competences: Arts 115 and 114 TFEU; Art. 352 TFEU.

${ }^{45} 2004$ Communication (note 35), at 9.

${ }^{46}$ Ibid., at 21.

${ }^{47}$ M. AmstutZ, Zwischenwelten. Zur Emergenz einer interlegalen Rechtsmethodik im europäischen Privatrecht, in C. JOERGES/ G. TEUBNER, Rechtsverfassungsrecht, BadenBaden 2003, at 237.

48 E.A. FARNSWORTH, Modernization and Harmonization of Contract law: and American perspective, (2003) Unif. L.R. 97, at 99-100: "The UCC along with our Restatements, has given us a system of common law that seems less startlingly different from Continental European legal systems than does English Common law".

${ }^{49}$ Measures Europeanising procedural law: Reg. 44/2001 on jurisdiction and the recognition and enforcement of judgments in civil and commercial matters, [2001] OJ L

Yearbook of Private International Law, Volume 13 (2011) 
cases as Keck and Tobacco Advertising underscored was that not every variance in domestic law necessarily threatens the integrity of the market as a whole..$^{50}$

\section{Commission's 2007 Green Paper on the Consumer Acquis}

The 2007 Green Paper marked the opening of a further consultative round. ${ }^{51}$ Yet as the 2007 Green Paper pre-dates the highly illuminating Acquis Report ${ }^{52}$ a crucial opportunity for communication was missed; fuelling suspicion that the Commission was aiming to orchestrate the debate. This in mind, it is striking that the 2007 Green Paper simply presented a catalogue of 31 questions. Moreover, in many instances, it was clear that for many of the questions there could only be one correct answer and a clearly wrong answer was also available. Furthermore, a number of the questions were non-questions: who would object to the harmonisation of cooling-off periods? ${ }^{53}$ Another group of questions were highly specialised: on the sale of second-hand goods at public auctions ${ }^{54}$ or the transferability of the commercial guarantee. ${ }^{55}$ The 2007 Green Paper thus seemed to map out a more modest field of vision: (1) re-dimensioning the "greater coherence" initiative to narrower objectives in consumer law; and (2) de-prioritising the work on the CFR and Optional Instrument, and embracing, instead, a "mixed approach" (horizontal/ vertical) to Consumer Law. ${ }^{56}$ This strategy was to involve: a Framework Directive on EC Consumer Contract Law (horizontal instrument) and a revision and improvement of the existing EC Consumer directives (vertical action).

12/1; Reg. 1206/2001 on co-operation between the courts of the Member States in the taking of evidence in civil or commercial matters, [2001] OJ L 174/1; Reg. 1348/2000 on the service in the Member States of judicial and extra-judicial documents in civil or commercial matters, [2000] OJ L 160/37; Reg. 1346/2000 on insolvency proceedings, [2000] OJ L 160/1; Reg. 805/2004 creating a European Enforcement Order for uncontested claims, [2004] $O J$ L 143/15; Directive 2003/8 to improve access to justice in cross-border disputes by establishing minimum common rules relating to legal aid for such disputes, [2003] $O J \mathrm{~L}$ 26/41. Finally, proposals on the introduction of a European Payment Procedure COM(2004) 173.

${ }^{50}$ Joined Cases C-267 \& 268/91, Keck and Mithouard, [1993] ECR I-6097; [1995] 1 C.M.L.Rev. 101, at paras 16-17; Joined Cases C-401 \& 402/92, Tankstation t' Heukste and J.B.E. Boermans, [1994] ECR I-2199, para. 12; N. REICH, The November Revolution of the Court of Justice: Keck, Meng and Audi Revisited, [1994] 31 C.M.L.Rev. 459; S. WeAtheriLl, After Keck: Some Thoughts on how to Clarify the Clarification, [1996] 33 C.M.L.Rev. 885. Limits of legislative competence: Tobacco (note 33).

${ }^{51} 2007$ Green Paper on the Consumer Acquis, $\operatorname{COM}(2006) 744$ final, 8 February 2007. Following: Commission's 1st Annual Progress Report on contract law and acquis review 2005, $\operatorname{COM}(2005) 456$ final.

${ }^{52}$ EC Consumer Law Compendium - Comparative Analysis 2006 (H. SCHUlteNOELKE (ed.)), available at $<$ http://ec. europa.eu/consumers/cons_int/safe_shop/acquis/ comp_analysis_en.pdf $>$.

${ }^{53}$ Ibid., s.4.8.1, Question F1, at 20-21.

${ }^{54}$ Ibid., s.5.2, Question H2, at 24-25.

${ }^{55}$ Ibid., s.5.10.2, Question M2, at 31 .

${ }^{56} \mathrm{Ibid}$., Option II, point 4.2 Option II: the mixed approach at 8-9. 
The EU Optional Instrument on a Common European Sales Law

\section{Evaluation of the 2007 Green Paper}

The Commission's position is to be set in a context of institutional support, ${ }^{57}$ this notwithstanding continuing legal base objections to the initiative. ${ }^{58}$ Yet even the "mixed approach" of the 2007 Green Paper contained some controversial aspects which would radically redefine the relationship between EU and national Consumer Law and expand the (horizontal?) reach of the approach: the apparent advocacy of a broader conceptualisation of the EU consumer (embracing the small business, the professional, entrepreneur and intermediary ${ }^{59}$ ), a tendency to the constrict freedom of contract (restrictions of liability on used goods and standard terms and conditions) and advocacy of an asymmetric norm on good faith on business in B2C transactions. ${ }^{60}$ Such amendments would not be available without a shift of competence to the centre and a Treaty revision. ${ }^{61}$

\section{E. The (D)CFR}

In 2009 Principles, Definitions and Model Rules of European Private Law: Draft Common Frame of Reference (DCFR) was finally published ${ }^{62}$ and the magnitude of this work is striking:

"The following volumes contain the results of the work of the Study Group on a European Civil Code....and the Research Group on Existing EC Private Law... Nearly two hundred and fifty people of different generations collaborated in the research groups over a period of more than twenty five years. They have reflected important areas of private law...The perspective is thoroughly European and...[m]odel rules, with comments and notes, bring together rules

57 Respectively: 2,784th Council meeting, February 19, 2007. Press Release 6044/07, p. 12. European Parliament Resolution of March 23, 2006 on European contract law and the revision of the acquis: the way forward, (2005/2022(INI)), available at $<$ www.europarl.europa.eu $>$.

${ }^{58}$ Tobacco Advertising (note 33), at para. 84; Case C-210/03, R. v Secretary of State for Health (Swedish Match), [2000] ECR I-11893, paras 26, 30-32, 34 and 68; S. WEATHERILL (note 3), at 646.

${ }^{59}$ Green Paper 2007 (note 51), at s. 4.2, Question B2, Option 2, p. 16-17.

${ }^{60}$ B. Heiderhoff/ M. Kenny, The Commission's 2007 Green Paper on the Consumer Acquis: deliberate deliberation?, (2007) 32 E.L.Rev. 740.

${ }^{61} \mathrm{~S}$. Weatherill, The Constitutional Competence of the EU to Deliver Social Justice, (2006) E.R.C.L. 2, at 136-158; S. WeatheriLl/ S. Vogenauer, The European Community's Competence for a Comprehensive Harmonisation of Contract Law- an Empirical Analysis, (2005) 30 E.L. Rev. 821, at 826.

${ }^{62}$ C. von BAR/ E. Clive (eds), Principles, Definitions and Model Rules of European Private Law: Draft Common Frame of Reference (DCFR), Oxford 2010. 
derived largely from the legal systems of the Member States and the over-arching Community law." ${ }^{63}$

The (D)CFR was published in six volumes, straddling ten "books", and including provisions relating to: general Contract Law (Books II \& III); specific types of contracts such as contracts relating to personal security (Book IV, Part G) and sales contracts (Book IV, Part A); non-contractual obligations (Book VI); Unjustified Enrichment (Book VII); and Trusts Law (Book X). However, perhaps the most hotly debated aspect of the (D)CFR was its ultimate purpose: was the (D)CFR a blueprint for a European Civil Code or was it, for example, merely to be used as a luxury toolbox? ${ }^{64}$ That controversy was partly fuelled by the EU Commission's Green Paper on policy options for progress towards a European Contract Law for consumers and businesses ${ }^{65}$ in which the Commission set out a number of options for the future of EU Contract Law which included: a Regulation establishing a European Civil Code (Option 7); a Regulation establishing a European Contract Law (Option 6); a Directive on European Contract Law (Option 5); and an optional instrument (Option 4). Yet, it soon became clear that an optional instrument was the most likely, and politically acceptable, option. ${ }^{66}$ The essential idea of an optional instrument was set out in the EU Commission's Green Paper on policy options for progress towards a European Contract Law for consumers and businesses:

"A Regulation could set up an optional instrument, which would be conceived as a 2nd Regime in each Member State, thus providing parties with an option between two regimes of domestic contract law. It would insert into the national laws of the 27 Member States a comprehensive... self-standing set of contract law rules which could be chosen by the parties...It would provide parties, primarily those wishing to operate in the internal market, with an alternative set of rules. The instrument could be applicable in cross-border contracts only, or in both cross-border and domestic contracts..." ${ }_{67}$

It also became clear that the scope of any legislative "CFR" would be much narrower than the (D)CFR, and indeed would probably relate to sales and some services contracts. ${ }^{68}$ However, beyond these indications, there was uncertainty on a number of issues including: the extent to which such an instrument would cover both business-to-business contracts and business-to-consumer contracts; whether

${ }^{63}$ Ibid., at 1.

${ }^{64}$ See, generally, S. Vogenauer, Common Frame of Reference and UNIDROIT Principles of International Commercial Contracts: Coexistence, Competition, or Overkill of Soft Law? (2010) 6 E.R.C.L. 143

${ }^{65} \mathrm{COM}(2010) 348$ final.

${ }^{66}$ J. Devenney/ M. Kenny, Unfair Terms and the Draft Common Frame of Reference: The Role of Non-Legislative Harmonisation and Administrative Co-Operation?, in J. Devenney/ M. Kenny, European Consumer Protection: Theory and Practice, forthcoming, CUP, 2012.

${ }^{67} \mathrm{COM}(2010) 348$ final.

${ }^{68}$ See, generally, S. Vogenauer (note 64). 
the instrument would be limited to cross-border transactions; the exact scope of the instrument; and, most importantly for this paper, the precise Private International Law dimensions to such an instrument. This uncertainty continued with the appointment of an Expert Group in 2010, ${ }^{69}$ its task being to:

"...conduct a feasibility study on a draft instrument of European contract law whatever its legal form or nature. Given that the Commission had yet to take a formal position on any of the options set out in the Green Paper, the Expert Group was asked to work on an "as if" basis drafting a study that could be used in different scenarios." 70

The next significant date was June 2011 when Commissioner REDING, speaking at a conference in Leuven, ${ }^{71}$ gave her support to the idea of an optional instrument:

"I have come to the conclusion that as regards contract law, we need a new approach...that on the one hand helps bring about the single market....while on the other hand respects Europe's legal diversity and the principle of subsidiarity. For me, this can be achieved by proposing a legal instrument on European Contract Law that is voluntary and optional. That can be chosen by businesses and consumers and then serves as basis for their transactions. That does not replace existing national contract law, but that would exist alongside it." 72

Yet, at that stage, there were still a number of issues to be resolved including, of particular relevance in the current context, the Private International Law dimensions to any optional instrument:

"We are still discussing the details of how this optional instrument should look like, and notably what should be its exact private international law effects. But one thing is clear: Nobody will be forced to use the optional instrument. The bottom line is choice. Only those who choose the instrument will be able to contract under it. Those who do not want to use it will continue to contract under national laws...It is... a very procompetitive way: the optional instrument will only become a success if many businesses and

\footnotetext{
${ }^{69}$ Commission Decision 2010/233/EU; (2010) OJ L 105/109.
}

70 Expert Group's Feasibility Study, p. 5 (emphasis added), available at $<$ http://ec.europa.eu/justice/contract/expert-group/index_en.htm $>$.

71 Towards a European Contract Law co-organised by the Study Centre for Consumer Law of the Catholic University of Leuven and the Centre for European Private Law of the University of Münster (Leuven, 3 June 2011).

${ }^{72}$ Commissioner Reding, The Next Steps Towards a European Contract Law for Businesses and Consumers, available at <http://europa.eu/rapid/pressReleasesAction.do? reference=SPEECH/11/411\&format=HTML\&aged=0\&language=EN\&guiLanguage=en $>$. 
consumers will find it attractive to make use of it for their transactions." ${ }^{73}$

Thereafter, in August 2011, a draft was produced which contained: provisions of "general" Contract Law (see Part II, III \& VI); provisions on the obligations and remedies of the parties to a sales contract or a contract for the supply of digital content (Part IV); and provisions on the obligations and remedies of the parties to a related service contract (Part V). ${ }^{74}$ Thereafter rumours began to emerge that a full proposal would be published in October 2011.

\section{F. The (Proposed) Common European Sales Law}

These rumours were true and on $11^{\text {th }}$ October 2011 a proposed (optional) Common European Sales Law (CESL) was published ${ }^{75}$ which adopted a similar structure to the August 2011 draft. Article 3 of the proposal states that:

"The parties may agree that the Common European Sales Law governs their cross-border contracts for the sale of goods, for the supply of digital content and for the provision of related services within the territorial, material and personal scope as set out in Articles 4 to $7 .{ }^{\prime 76}$

Article 7 of the proposal states:

"The Common European Sales Law may be used only if the seller of goods or the supplier of digital content is a trader. Where all the parties to a contract are traders, the Common European Sales Law may be used if at least one of those parties is a small or mediumsized enterprise («SME»).”

Yet, significantly, it is proposed that Member States be given the power to extend the use of the CESL:

"A Member State may decide to make the Common European Sales Law available for:

(a) contracts where the habitual residence of the traders or, in the case of a contract between a trader and a consumer, the habitual residence of the trader, the address indicated by the consumer, the delivery address for goods and the billing address, are located in that Member State; and/or

${ }^{73}$ Ibid.

${ }^{74}$ Available at $<$ http://ec.europa.eu/justice/contract/index_en.htm $>$.

75 Available at <http://ec.europa.eu/justice/contract/files/common_sales_law/ regulation_sales_law_en.pdf $>$.

${ }^{76}$ Emphasis added. 
(b) contracts where all the parties are traders but none of them is an SME within the meaning of Article 7(2)." ${ }^{77}$

\section{Reflections on the (Proposed) Common European Sales Law}

The proposed CESL will no doubt stimulate much debate; and that debate is likely to include issues related to the methodology adopted in the (D)CFR; the drafting of the CESL $;{ }^{78}$ the assumptions underpinning the need for an optional instrument; ${ }^{79}$ and the precise Private International Law implications of an optional instrument. The latter will be discussed in Part IV of this paper; in this section of the paper we will discuss four further issues/challenges for the CESL:

- fragmentation;

- consistency of interpretation;

- the impact of social, cultural and economic norms; and

- the enforcement of consumer protection provisions.

\section{A. Fragmentation}

In relation to fragmentation, we have already noted that existing EU initiatives in this area have been criticized on the ground that they have resulted in fragmen-

${ }^{77}$ Proposed Article 13.

${ }^{78}$ Prior to the publication of the proposed CESL, the Department for Business, Skills and Innovation and Ministry of Justice asked the Law Commission and the Scottish Law Commission to provide advice to the UK Government on the idea of an optional instrument: see: <http://www.scotlawcom.gov.uk/law-reform-projects/contract-law-in-light-of-the-draftcommon-frame-of-reference-dcf/ $>$. Shortly after the publication of the proposed CESL, the Law Commission and the Scottish Law Commission published their advice to the UK Government: An Optional Common European Sales Law: Advantages and Problems Advice to the UK Government (November 2011), available at $<\mathrm{http} / /$ www.justice.gov.uk/lawcommission/docs/Common_European_Sales_Law_Advice.p $\mathrm{df}>$. In that advice the Law Commissions had their doubts about the proposal which, they argued, was not always easy to follow: "Distance selling needs its own clear rules, designed around automated processes. The CESL is based on more general contract law principles and we think that it would benefit from greater focus on distance sales. More could be done to clarify when the contract is formed; the effect of a change of circumstances; and unfair terms protection. Provisions on the transfer of property could also usefully be inserted" (S. 14).

${ }^{79}$ In their advice the Law Commission and the Scottish Law Commission were not convinced about the merits of pursuing a CESL in relation to commercial contracting (S.51). The Law Commissions were, however, more supportive of a CESL for some consumer sales (S.51): "We think efforts would be better spent on developing a European code for consumer sales over the internet, where there is stronger evidence that the current variety of contract laws inhibits the single market." 
tation. Yet the proposed CESL would also result in fragmentation, albeit that that fault lines may have shifted. More specifically the CESL does not cover all aspects of the sales relationship:

"All the matters...that are not addressed....are governed by the preexisting rules of the national law...under Regulations (EC) No $593 / 2008$ and (EC) No 864/2007 or any other relevant conflict of law rule. These issues include legal personality, the invalidity of a contract arising from lack of capacity, illegality...the language of the contract, matters of non-discrimination, representation, plurality of debtors and creditors, change of parties...set-off and merger, property law including the transfer of ownership, intellectual property law and the law of torts." ${ }^{80}$

In addition there is also the question of the interaction between the CESL and (nonharmonised) areas of law outside of the CESL. Here we are reminded of the work of two of the present authors on the protection of non-professional sureties. ${ }^{81}$ Surety transactions are an interesting case study for any harmonisation agenda as such contracts are polycontextual in nature; in other words such transactions transcend traditional legal boundaries. Thus surety transactions involve aspects of:

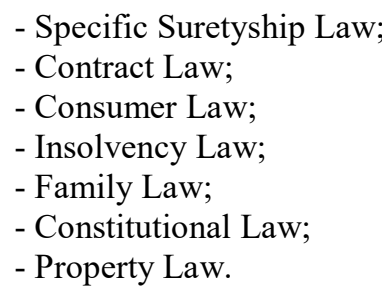

The key point for present purposes is that, whilst most Member States have attempted to increase surety protection, there is marked diversity in the means used. $^{82}$ In particular surety protection in individual Member States involves different complex orchestrations of these legal fields, concepts and mechanisms. ${ }^{83}$ This may mean that tinkering with one of these elements may have very different consequences in different Member States. ${ }^{84}$ Similarly harmonising zones of the

${ }^{80}$ Proposed Recital 27.

${ }^{81}$ M. Kenny/ J. Devenney, The Fallacy of the Common Core: Polycontextualism in Surety Protection - a Hard Case in Harmonisation Discourse, in M. ANDENÆS/ C. ANDERSEN (eds), The Theory and Practice of Harmonisation (forthcoming, Edward Elgar Publishing, 2012).

${ }^{82}$ See A. Colombi Ciacchi, Non-legislative Harmonisation of Private Law under the European Constitution: the Case of Unfair Suretyships, (2005) 13 E.R.P.L. 297.

${ }^{83}$ See J. Devenney/ M. Kenny, Unfair Terms, Surety Transactions and European Harmonisation: a Crucible of Europeanised Private Law?, [2009] Conveyancer and Property Lawyer 295.

${ }^{84}$ See M. Kenny/ J. Devenney, The Fallacy of the Common Core: Polycontextualism in Surety Protection - a Hard Case in Harmonisation Discourse, in M. ANDENÆS/ C. ANDERSEN (note 81). 
sales relationship may sometimes have different consequences in different Member States.

\section{B. Consistency of Interpretation}

Turning to the issue of consistency of interpretation, one of the advantages of an optional instrument envisaged by the EU Commission's Green Paper on policy options for progress towards a European Contract Law for consumers and businesses was that:

"Consistent reference to a single body of rules would remove the necessity for judges and legal practitioners to investigate in certain cases foreign laws, which is currently the case under conflict-of-law rules. This could not only reduce costs for businesses, but also alleviate the administrative load on the judicial system." 85

The central difficulty, of course, relates to ensuring both consistency of interpretation throughout all Member States and a "European" approach to the interpretation of any CESL when, under existing Europeanized Private Law, there has been some notable unevenness in interpretation throughout the EU. ${ }^{86}$ Indeed even within the same Member State there has sometimes been some unevenness of interpretation. ${ }^{87}$ The latter point can be illustrated by reference to the case law ${ }^{88}$ in England and Wales on the vexed question of (in effect) whether or not the Unfair Terms Directive applies to non-professional surety transactions. ${ }^{89}$ From a formal perspective, a difficulty with applying the Unfair Terms in Consumer Contracts Regulations 1999 (the Regulations which seek to transpose the Unfair Terms Directive in England and Wales) to such transactions is that (assuming that the surety can be classified as a "consumer" for the purposes of the Regulations) it is the non-professional surety who supplies the service; whereas the creditor, as beneficiary of the agreement, will usually be acting in the course of business. ${ }^{90}$ Therefore this question is part of the much wider debate as to whether or not, for the purposes of the Regulations, the consumer must be the recipient of goods or services. ${ }^{91}$

\footnotetext{
${ }^{85} \operatorname{COM}(2010) 348$ final (emphasis added).

${ }^{86}$ See J. DeVENNEY/ M. KENNY (note 83).

${ }^{87}$ Ibid.
}

${ }^{88}$ See, generally, J. DevenNey, Gordian knots in Europeanised private law: unfair terms, bank charges and political compromises, (2011) 62 N.I.L.Q. 33.

${ }^{89}$ See G. McCormack, Protection of Surety Guarantors in England - Prophylactics and Procedure, in A. Colombi Ciacchi (ed.), Protection of Non-Professional Sureties in Europe: Formal and Substantive Disparity, Baden-Baden 2007, at 172-173.

${ }^{90}$ See J. O’Donovan/ J. Phillips, The Modern Contract of Guarantee, London 2003, p. 223. 032.

${ }^{91}$ See H.G. Beale (ed.), Chitty on Contracts, 30th edn., London 2008, at para. 15- 
Support for the view that the Regulations do apply to surety transactions can be found in the Opinion of the European Court of Justice in Bayerische Hypothetken- und Wechselbank v. Dietzinger. ${ }^{92}$ In that case the European Court of Justice had to consider the applicability of Council Directive 85/577/EEC (on contracts negotiated away from business premises) to surety transactions. In a Judgment, which is not without controversy, ${ }^{93}$ the European Court of Justice stated that:

“...it is apparent from the wording of Article 1 of Directive 85/577 and from the ancillary nature of guarantees that the directive covers only a guarantee ancillary to a contract whereby, in the context of "doorstep selling", a consumer assumes obligations towards the trader with a view to obtaining goods or services from him. Furthermore, since the directive is designed to protect only consumers, a guarantee comes within the scope of the directive only where, in accordance with the first indent of Article 2, the guarantor has entered into a commitment for a purpose which can be regarded as unconnected with his trade or profession. ${ }^{94}$

In reaching this conclusion, which gives a glimpse of how the CJEU might approach this issue in the context of the Unfair Terms Directive, ${ }^{95}$ the European Court of Justice noted that nothing in the Doorstep Selling Directive required "the person concluding the contract under which goods or services are to be supplied be the person to whom they are supplied"96 and that surety agreements are merely ancillary to the main contract. ${ }^{97}$ Returning to the case law in England and Wales, in Barclays Bank Plc v. Kufner ${ }^{98}$ Field J., relying heavily on the Opinion of the European Court of Justice in Bayerische Hypothetken- und Wechselbank $v$. Dietzinger $^{99}$ - held that surety transactions are not excluded from the scope of the Regulations. ${ }^{100}$ By contrast in Bank of Scotland v. Singh ${ }^{101}$ Judge Kershaw QC,

${ }^{92}$ Case C-45/96, Dietzinger, [1998] ECR I-1199.

${ }^{93}$ See M. Kenny, Standing Surety in Europe: Common Core or Tower of Babel, (2007) M.L.R. 175, at 180.

94 Dietzinger (note 92), at para. 20. Although cf. Berliner Kindl Brauerei AG v. Andreas Siepert, [2000] ECR 1-1741, paras 25-26, where the European Court of Justice, in considering Council Directive $87 / 102 / \mathrm{EEC}$ for the approximation of the laws, regulations and administrative provisions of the Member States concerning consumer credit, noted: "...the scope of the Directive cannot be widened to cover contracts of guarantee solely on the ground that such agreements are ancillary to the principal agreement whose performance they underwrite, since there is no support for such an interpretation in the wording of the Directive...or in its scheme and aims."

${ }^{95}$ See H.G. BeAle (ed.) (note 91), at para. 44-139.

${ }^{96}$ Dietzinger (note 92), at para.19.

${ }^{97}$ Ibid., at para. 18.

98 [2008] EWHC 2319 (Comm).

${ }^{99}$ Dietzinger (note 92).

${ }^{100}$ Kufner (note 98), at para. 28.

${ }^{101}$ (QBD, unreported, 17 $7^{\text {th }}$ June 2005). 
apparently operating closer to the actual wording of the Regulations, held that the Regulations did not apply to surety transactions and his view has subsequently been described as "compelling" 102 and "convincing". ${ }^{103}$

Of course an efficient and robust reference process to the CJEU might act as an interpretative compass for any CESL. Yet the existing reference procedure is not always perceived as having such qualities. Thus in Page v. Combined Shipping and Trading Co Ltd ${ }^{104}$ Staughton LJ famously stated:

"...the French, German and Italian versions all of which use the word «normal/normale» instead of «proper». That does not necessarily mean the same as «normal» in English; similarities in language can be deceptive... we ought to conclude that Mr Page has a good arguable case...It may well be that when this comes to trial we shall have to refer the problem to the European court, and it will take another two years after that before a decision emerges as to what the regulation really means. Maybe the parties will think there are better methods of spending their time and their money than disputing that for a long period of time."

\section{Application of Rules}

Moreover, even if a particular rule is being interpreted consistently throughout the EU, the application may be different as a result of local considerations. To some extent, this was recognised in Freiburger Kommunalbauten GmbH Baugesellschaft \& Co. KG v. Ludger Hofstetter and Ulrike Hofstetter ${ }^{105}$ where the ECJ noted that it "may interpret general criteria used by the Community legislation in order to define the concept of unfair terms. However, it should not rule on the application of these general criteria to a particular term". ${ }^{106}$ More specifically this issue can be illustrated by the interaction of the unfairness test under the Unfair Terms Directive and background rules:

"the application of the same general criterion in two Member States may give rise to very different decisions, as a result of the divergences between the rules of substantive law that apply to different contracts. Hence harmonisation under the Directive is more apparent than real." 107 Price QC.

${ }^{102}$ Manches LLP v. Carl Freer, [2006] EWHC 991, at para. 25, per Judge Philip

${ }^{103}$ Williamson v. Governor of the Bank of Scotland, [2006] EWHC 1289, at para. 46 per George Bompas QC, sitting as a Deputy Judge.

104 [1996] C.L.C. 1952, at 1956.

${ }^{105}$ [2004] ECR-I 3403.

${ }^{106}$ Ibid., at para. 22.

107 Report on Directive 93/13/EEC on Unfair Terms in Consumer Contracts, $\operatorname{COM}(2000) 248$ final, at 30. 
Thus in UK Housing Alliance (North West) Ltd v. Francis ${ }^{108}$ the (non-harmonised) protection that could be offered by courts in England and Wales in possession proceedings contributed to a finding that a term in a sale and leaseback arrangement was not unfair under the Unfair Terms in Consumer Contracts Regulations 1999. An allied point is that the social, cultural and economic norms in a particular Member State may affect the application of some of the tests under any optional instrument. Again this may be illustrated by the Unfair Terms Directive, which is transposed in the UK by Regulation 5(1), Unfair Terms in Consumer Contracts Regulations 1999:

"A contractual term which has not been individually negotiated shall be regarded as unfair if, contrary to the requirement of good faith, it causes a significant imbalance in the parties' rights and obligations arising under the contract, to the detriment of the consumer."

Of course pivotal to the operation of Regulation 5 is how "good faith" is conceptualised. ${ }^{109}$ This was an issue addressed by Lord Bingham in Director General of Fair Trading v. First National Bank plc ${ }^{110}$ where His Lordship stated:

"Good faith in this context is not an artificial or technical concept; nor, since Lord Mansfield was its champion, is it a concept wholly unfamiliar to British lawyers. It looks to good standards of commercial morality and practice." 111

The key point for present purposes is that such a test is inevitably loaded with social, cultural and economic norms and there are differences in such norms throughout the EU. ${ }^{12}$

\section{Consumer Protection and Enforcement}

Commissioner Reding has noted that: "The right balance between business and consumer interests is...key to the success of the optional instrument." ${ }_{113}$ By contrast, the Expert Group's Feasibility Study stated: ${ }^{114}$

\section{${ }^{108}$ [2010] EWCA Civ 117.}

109 See generally M. Kenny/ J. Devenney/ L. Fox O’Mahony, Conceptualising Unconscionability in Europe: in the Kaleidoscope of Private and Public Law, in M. KenNY/ J. DevenNey/ L. Fox O'MAHONY (eds), Unconscionability in European Private Financial Transactions: Protecting the Vulnerable, Cambridge 2010, at 377.

${ }^{110}$ [2002] UKHL 52.

${ }^{111}$ Ibid., at para.17.

${ }^{112}$ P. O'Callaghan, Protection from Unfair Suretyships in Ireland, in A. Colombi CIACCHI (note 89 ).

${ }^{113}$ Commissioner Reding, The Next Steps Towards a European Contract Law for Businesses and Consumers, June 2011.

${ }^{114}$ See (note 70$)$, at 6 . 
"As part of the feasibility study, the Commission tasked the Expert Group with drafting contract law rules which would afford consumers a high level of protection in business-to consumer contracts."

The argument is essentially that in order to induce consumers to use the optional instrument, the level of consumer protection needs to be high. If so, careful thought needs to be given to the enforcement of consumer protection provisions in any optional instrument. For example, the role of collective proceedings in the regulation of unfair terms, consumers often not having the information, resources and/ or inclination to challenge "unfair" standard terms in the courts. ${ }^{115}$

\section{Private International Dimensions to the CESL}

\section{A. The CESL: An Optional Set of National Contract Law Rules}

As a set of second order rules, ${ }^{116}$ Private International Law seeks to regulate the related questions of which court has judicial authority to hear a dispute with a foreign element, what law applies to such disputes and how a judgment from one court is recognised and enforced in another court. The current "third wave" 117 of European-led Private International Law is of increasing importance not only in regulating ${ }^{118}$ the appropriate application of substantive laws to commercial and personal disputes, but also in ensuring that private rights are recognised through the choice of law process. ${ }^{119}$ In the fifteen years since the Treaty of Amsterdam, the EU's competence in the field of Justice and Home Affairs has enabled the EU to extend internal and affirm external competence in matters relating to "the conflict of laws and jurisdiction." ${ }_{120}$ Such competence in foro exterior has been justified,

${ }^{115}$ H. BEALE, Legislative Control of Fairness: The Directive on Unfair Terms in Consumer Contracts, in J. BeATSON/ D. Friedmann (eds), Good Faith and Fault in Contract Law, Clarendon/ Oxford 1995.

${ }^{116}$ H. Muir-WATt, The Role of the conflict of laws in European private law, in C. Twigg-Flesner (ed.), The Cambridge Companion to European Union Private Law, Cambridge 2010; A. Mills, The Confluence of Public and Private International Law, Justice, Pluralism and Subsidiarity in the International Constitutional Ordering of Private Law, Cambridge 2010.

${ }^{117}$ L. GILLIES, "Re-Conceptualising Conflicts Justice via the Approximation of Residual Jurisdiction in EC 44/2001" on file with author.

118 H. Muir-WatT, note 116 at p.54 Private International Law as Global Governance: From Closet to Planet, Research Paper for the launch of the Private International Law as Global Governance Research Programme, available at $<$ http://blogs.sciences-po.fr/pilagg/>>

${ }^{119}$ Case C-148/02, Garcia v Belgium, [2003] ECR I-11613; Case C-353/06 Grunkin and Paul, [2008] ECR I-7639 ; Negrepontis-Giannisis v Greece, Application No.56759/08, unreported 3 May 2011, ECHR.

120 Article 65, TEU, Article 81 TFEU; Regulation EC 593/2008 on the Law Applicable to Contractual Obligations (hereafter the "Rome I Regulation"), Recitals (4) and (6). 
and confirmed by the Court of Justice, ${ }^{121}$ on the premise of responding to the needs of the internal market ${ }^{122}$ either on the basis of such rules impeding one of the fundamental freedoms or distorting competition. ${ }^{123}$ As stated earlier, the effective application of the CESL will depend upon its interaction with the Rome I Regulation, ${ }^{124}$ when enacted as a second (or supplementary), optional ${ }^{125}$ substantive Contract Law applicable to contracts conducted between the EU Member States. Parties situated in different jurisdictions must be able to ascertain with certainty the law applicable to their obligations and the consequential effect of those laws in order, as FENTIMAN alludes, to assess and determine transaction and litigation risks associated with commercial activities. ${ }^{126}$ Two key issues raised by the recent Joint Law Commissions of England and Wales and Scotland's Report ${ }^{127}$ on the proposed CESL instrument questioned not only its justification but its anticipated effectiveness as a supplementary set of substantive contract rules for cross-border sales. An important point raised by that Joint Report was whether the proposal, in addition to applying to cross-border sales, ought to be extended to sales conducted internally within a Member State. ${ }^{128}$ Such matters are relevant to the private international lawyer when determining whether the law of a given State or, in the case of the United Kingdom, a particular part of that State is to apply to a contract. Whilst it is fully recognised that the CESL does not purport a choice of either a separate law or system of law, ${ }^{129}$ its interaction with existing choice of law rules for contractual obligations in business to business and business to consumer transactions in the Rome I Regulation are worthy of examination. It will also consider the potential interaction of the proposal with the provisions in the Rome I Regulation regarding mandatory rules. Since the CESL is an "optional" limb of Contract Law, it is suggested that the impact of the proposed instrument with the Rome I Regulation will be limited to only those situations where the parties have made an express choice of law (Article 3). Its impact as a targeted maximum harmonisation measure in regulating contractual regulations ergo the substantive law of a cross-border consumer contract has the potential to (i) increase business confidence by reducing related compliance costs and, in the case of cross-border

${ }^{121}$ Opinion $1 / 03$ of the Court on the competence of the Community to conclude the new Lugano Convention on jurisdiction and the recognition and enforcement of judgments in civil and commercial matters, [2006] ECR I-1145.

${ }^{122}$ Article 114 TFEU.

${ }^{123}$ A. Dickinson, European Private International Law: Embracing New Horizons or Mourning the Past?, 2005 J.P.I.L. 197, at 216.

${ }^{124} \mathrm{~A}$ point alluded to in the proposal; $\operatorname{COM}(2011) 635$ final, at 5-6.

${ }^{125}$ M. W. Hesselink, How to Opt Into the Common European Sales Law? Brief Comments on the Commission's Proposal for a Regulation, Amsterdam Law School Legal Studies Research Paper No. 2011-43/Centre for the Study of European Contract Law Working Paper No. 2011-15, available at $<$ http://ssrn.com/abstract $=1950107>$, (accessed 16 January 2012), p. 12.

${ }^{126}$ R. FENTIMAN, International Commercial Litigation, Oxford 2010.

${ }^{127}$ The Law Commission and the Scottish Law Commission, above (note 78).

${ }^{128}$ Ibid., at S. 18.

${ }^{129}$ M. W. HesselinK (note 124), at 1. 
consumer contracts, (ii) improve protection for the "active consumer" (a consumer who transacts with a business located in another Member State). ${ }^{130}$ To that extent, the ability of the consumer to be able to sue the business in his home jurisdiction (in accordance with Article 15(1)(c) of Regulation EC 44/2001 ${ }^{131}$ ) remains of paramount significance.

\section{B. The CESL, and the Rome I Regulation: Business to Business Contracts}

\section{Article 3: Freedom of Choice}

The starting point in the Rome I Regulation for determining the applicable law of a business-to-business sales contract is Article 3. Under Article 3(1), provided the matter is of a "civil or commercial nature," parties are free to select (and vary) the law applicable to their contractual obligations. Such a choice has to be "expressed or demonstrated with reasonable certainty." As far as the "law applicable to their contractual relations" is concerned, the law must be that of a territorial unit (that is, the law of a country) or in accordance with Recital 13, a system of law (such as the CISG). This distinction is significant when considering the potential interaction between the CESL and Article 3 of the Rome I Regulation. Recital 14 of the Rome I Regulation explains that the application of codified Community rules on substantive contract law, such as the draft Common Frame of Reference and now the proposed CESL, are alse is a permitted choices. Therefore, the CESL is novel in the sense that it is a particularised, or as HESSELINK remarks hybrid, ${ }^{132}$ set of (EU private) law rules for cross-border contracts. Since the proposed vehicle for implementing the proposal is a Regulation, its temporal scope would become a new branch or limb within the national contract laws of the Member States. The crux of the proposal for the CESL, like the Rome I Regulation itself, is based on party autonomy. Provided the choice in favour of the optional instrument has been expressly made, the CESL may be selected by the parties as the applicable law of $a$ Member State. On a number of occasions the proposal makes it clear that the rules are intended to be secondary to existing national contract laws. Therefore, one of the key benefits of the CESL proposal is that it increases the parties' choice of applicable law within the law of a territorial unit. The practical impact of the proposal will be the extent to which it is the proposals are more attractive to businesses in place of their national law as their standard choice of law.

\footnotetext{
${ }^{130}$ On the assumption that the measure offers greater protection through targeted maximum harmonisation than currently offered to such consumers; on which see M. W. HeSSELINK (note 124), at 3.

${ }^{131}$ Regulation EC 44/2001 is currently under review: COM(2010) 748 FINAL (COD 2010/0383), 14 December 2010.

${ }^{132}$ See M. W. HesselinK's discussion on the "national" emphasis of the proposal (note 124$)$, at 6.
} 


\section{Scope of CESL: An Improved Option for Businesses?}

Rather than operating as a system of law such as an international Convention or instrument, ${ }^{133}$ the CESL only enters the picture when a particular national law has been identified and agreed upon as the applicable law. However, increased choice comes at a price. If the objective of the proposal is essentially for traders to anticipate and thereby limit transaction and litigation risk, the "optional" nature of the proposal will inevitably mean that traders will have to make an additional risk assessment particular to their business and its operations and only then decide whether or not to opt in to the CESL in place of their "standard" existing choice of law national contract laws. Even if the parties contract stipulates the CESL in accordance with Article 3(1), as with any other choice of law, it is subject to overriding mandatory rules of the lex fori (Article 9(2) or the lex loci solutionis (Article 9(3)). A basic scenario may be presented. Two businesses, each located in different Member States, enter into a contract of sale. Asssuming no prior course of regular dealing or a change to the applicable law as a result of prior dealing, it is at this stage that the choice of the CESL may be selected. At this point, the seller is likely to impose his own law by way of agreement in the contract. Such an agreement must be valid (i.e. expressed or demonstrated with reasonable certainty) in accordance with Article 3. However, by virtue of Article 9, overriding mandatory provisions may circumvent or limit the parties' choice either when such provisions are applicable in accordance with the lex fori or the lex loci solutionis (normally the place of performance, such as the place delivery of the goods under the contract of sale if different from the lex fori or the lex loci contractus).

Therefore, if the parties agreed a choice of law and within that choice selected the CESL as the opt-in limb of the applicable law, in theory it it would be potentially more straightforward for both parties to predict the consequences of their contractual relations than if the basie standard contract law of the seller's habitual residence was selected (subject to mandatory rules). This does not necessarily mean however that the seller would wish to forgo the standard substantive contract rules where it is based. Given that the objective of the proposal is a maximum harmonisation instrument, it is hard not to view the effect of this proposal as anything other than a set of opt-in EU wide mandatory provisions. In addition to its limited application when selected as an optional national law, the proposal is also restricted to contracts having connections to Member States.

A question raised by the recent United Kingdom's Law Commissions' joint report was whether the CESL should apply to internal contracts within a Member State as well as to contracts with foreign elements. ${ }^{134}$ This question raises an interesting wider issue related to the nature of the CESL (whether a system of law in itself or as an optional limb of national law). It also highlights that businesses with compliance costs and greater transaction risk due to cross-border selling are the focus of attention of this proposal, not necessarily businesses competing and operating within the same Member State. A consideration of the interaction

${ }^{133}$ On the potential "interaction" between the CESL and the CISG (which does not apply in the United Kingdom) see M. W. HesselinK (note 124), at 3 et seq. and Recital 25 of the proposal.

${ }^{134}$ The Law Commission and the Scottish Law Commission, (note 127). 
between the CESL and Articles 3(3) and 3(4) of the Rome I Regulation is still instructive. For example if two businesses are both situated in France and entered into a contract of sale, one could reasonably assume that French Law ought to meet both parties' reasonable expectations. As currently proposed, the CESL could not be selected by the parties where the matter is internal within a Member State. However, if the parties selected German Law to govern their contract on the basis that performance of the contract was to take place in Germany, Article 3(3) would apply. Article 3(3) is designed to limit the parties' choice from evading French mandatory provisions. This scenario assumes that an entirely different ational (country's) law has been selected in place of the law where both parties are habitually resident. Placing the significant matters of implementation, authenticity of the language versions of the CESL and its (expectantly, autonomous) interpretation to one side, Having selected German Law as the applicable law, placing the significant matters of implementation and the expected equivalence in authenticity of language and autonomous interpretation to one side, two questions remain. Can the parties go further and select the German version of the CESL and if so, would such a choice be overridden in circumstances intended to apply applicable under where Article 3(3) applies? The rationale of the CESL proposal is to facilitate additional choice within a particular country's law (once chosen) rather than as a system of non-State rules. However, rather than merely stating that the Rome I Regulation will be "unaffected by the proposal" 135 the interaction with Article 3(3) requires to be clarified. If the objective of the proposal is to provide (targeted) maximum harmonisation rules across the Member States, it must be clarified whether the parties in the example above would be prevented barred from selecting the CESL of another country in the first instance because their contract is an internal contract. If the parties are in the same Member State it is not clear at this stage whether (a) the CESL should apply and (b) can apply as a different language version when a foreign law is chosen in circumstances related to Article 3(3). The ability to select another law under Article 3(3) would therefore be restricted to the prineipal national law of that country. Either the CESL should apply to all contracts (internal or cross-border) or the position of internal contracts should be clarified in both future drafts of the CESL and when the Rome I Regulation comes to be revised.

The remit of the proposal should also be clarified vis-a-vis its future interaction with Article 3(4) of the Rome I Regulation. If the contract is connected to more than one Member State, and the law of a non-Member State is selected, the contractual choice is subject to the overriding rules of Community law, as implemented by the lex fori. Again, in view of its objective as a targeted harmonisation measure, clarification is required on whether the CESL is to be regarded as a mandatory provision (in view of its objective as a targeted harmonisation measure) of Community law or merely as an optional set of secondary national rules. Given the objective to implement common rules for business to business sales contracts within the Community, the optional nature of the CESL puts a greater emphasis on how non-EU businesses determine their contractual choice of law preferences. The proposal should consider the extent to

${ }^{135} \mathrm{COM}(2011) 635$ final (note 124), at 6. 
which the combination of Article 3(4) and the operation of mandatory EU laws facilitate cross-border trade on an equivalent basis to contracts where the CESL has been selected by the parties.

\section{Interaction with Article 4: Applicable Law in the Absence of Choice}

As is well known, the Rome I Regulation provides rules to determine the applicable law where an express or implied choice has been made or where no choice has been made by the parties. Since the CESL is currently proposed as a purely optional instrument to be selected within a national system of law selected by the parties, it has no bearing on Article 4 of Rome I. However, the objective of the proposal is to secure maximum harmonisation. Whilst the number of crossborder contracts which fail to specify a choice of law are likely to be negligible, the he scope of the proposed CESL requires to be clarified for the purposes of determining to what extent it may or may not apply in the situation where no applicable law has been selected by the parties. Article 4 of Rome I determines the applicable law in the absence of choice for a variety of situations. In the case of the sale of goods, the applicable law is the law of the characteristic performer's (i.e. the seller's) habitual residence. If the CESL seeks to equip parties with improved choice in determining the basis of their contractual obligations, only applicable on the basis of the parties' express choice, then the applicable law rules in the absence of choice would not facilitate the application of a CESL, optional or otherwise. Whilst this reiterates the need for the parties to actively select the CESL, it does limit its utility where no choice of law has been made. The question arises that if the objective of maximum harmonisation is to be sufficiently met, should the CESL apply by default in such situations where consumers or micro enterprises merit protection in cross-border activities?

\section{The CESL and the Rome I Regulation: Business-to-Consumer Contracts}

Under Article 6(1)(a) of the Rome I Regulation, the law of the consumer's habitual residence applies in a situation where the business "pursued his commercial or professional activities in the country where the consumer has his habitual residence." ${ }^{136}$ When a business operates within a particular jurisdiction and concludes contracts there, it is entirely legitimate (and arguably not a cross border case) for the law of the consumer's habitual residence to apply. Alternatively, Article 6(1)(b) also enables the law of the consumer's habitual residence to apply if a business - instead of pursuing commercial activities "in the country", "by any means, directs such activities to that country or to several countries including that country." ${ }^{137}$ In the context of a cross-border sale, the challenges to a business (of whatever size) of such consumer protection requires that business to assess the

\footnotetext{
${ }^{136}$ Article 6, Rome I Regulation.

${ }^{137}$ Ibid.
} 
extent of transaction risk with consumers in different jurisdictions and implement litigation risk strategies by ensuring commercial activities were directed or "intentionally targeted" 138 towards particular jurisdictions whilst, by implication, actively avoiding other. ${ }^{139}$ As a buffer to the imposition of a choice of law rule in favour of the consumer's law, Article 6(2) of Rome I enables parties to a consumer contract to agree the law applicable to their contract. This choice is subject to the mandatory rules of the consumer's habitual residence. Therefore, the business can impose its preference upon the consumer contract but its choice is still restricted. The objective of the CESL proposal is to maximise consumer protection rules, but it only does so for cross-border sales. It would not therefore affect contracts falling under Article 6(1)(a) but apply instead to cross-border contracts falling under Article 6(1)(b). The interaction between Article 6(1)(b), Article 6(2) and the CESL should be clarified. As HESSELINK ${ }^{140}$ has suggested, the effect of the proposal is to diminish more stringent consumer protection measured under national law, it is questionable whether the objective of the proposal is firmly ground in enhancing consumer protection objectives under Article 114 TFEU or, as is more readily identifiable, discretely focussed on meeting the needs of businesses operating in the internal market, thereby reducing distortions of competition.

\section{E. What Does the Proposal Say Regarding Validity, Consent and Illegality?}

A short answer to this is: not a lot. ${ }^{141}$ Some brief comments may be made on matters affected by the choice of an applicable law. Issues of validity are matters for the substantive law concerned, not for "secondary" 142 applicable law rules. According to the Rome I Regulation, any question of validity or illegality of the contract or whether a party seeks to argue that he did not consent to the contract, are matters for the putative applicable law (i.e. the law that would apply, if the choice is a valid choice of law) by virtue of Article 10. Any such questions therefore can only be answered once a choice has been validly ascertained in accordance with either Article 3 (express choice: where the CESL could apply) or Article 4 (absence of choice). This means potentially two things for the CESL proposal. Either the proposal should refer the matters of validity, illegality of lack of consent to the principal national law of the Member State under which the Common Sales Law has been selected or it should as a complete set of proposals designed to enhance cross-border commercial and consumer sales provide rules on the extent to which a contract is held to be formally and essentially valid on the one hand and illegal on the other. If the CESL is silent on the matter, the parties would

${ }^{138}$ L.E. GiLLIES, Electronic Commerce and International Private Law, A Study of Electronic Consumer Contracts, Ashgate/ Aldershot 2008.

139 J.S.T ØREN, International Jurisdiction Over Consumer Contracts in e-Europe, (2003) 52 I.C.L.Q. 665.

${ }^{140}$ M. W. HESSELINK (note 125)

${ }^{141} \operatorname{COM}(2010) 348$ final (note 124), at 6.

${ }^{142}$ A. Mills (note 116), at 19. 
be required to consult the (principal) national contract law rules on such matters. Whether this would amount to unnecessary dépeçage of the contract remains to be seen. In any event, if the CESL is to provide a complete optional set of rules, which are designed to limit compliance, costs and transaction risks, it should take the logical step further and provide specific rules determining the validity and illegality of a contract where the CESL has been chosen. The CESL should also address specifically the manner of its interpretation in the light of its objectives to provide maximum harmonisation. In order to achieve consistency (i) between the CESL and the Rome I Regulation (ii) when applied between the Member States and, (iii) depending on the instrument to be used, an autonomous interpretation should be observed.

\section{F. Underlying Choice of Law Issues to Be Resolved}

Whether the proposed CESL will be purely applicable to cross-border sales or also to internal sales the Commission has suggested that it will not impact upon the Rome I Regulation to any great extent. However, as this section has sought to demonstrate, there are a number of matters that require to be considered in the light of the Rome I Regulation. In the case of business to business contracts, its interaction with Article 3(1) and (3) requires to be clarified. In the case of business to consumer contracts, it provides a set of substantive rules that operate in crossborder situations but will not apply to internal sales, which may actually lead to the two tier system identified by the Law Commission in their report, ${ }^{143}$ ergo a more stringent set of national consumer protection laws operating for internal sales contracts (where no choice of law issues arise) and another set of (arguably reductionist) targeted, harmonised laws for cross-border sales (where the choice of law issues are their most acute for consumers and SMEs and most expensive for businesses). Since the consumer cannot currently be deprived of the law of his habitual residence in cross-border sales, it remains to be seen whether the CESL will equip consumers with any greater protection. By comparison, the benefit of a cross-border CESL as between EU businesses is a non sequitur.

\section{Closing Remarks}

As Commissioner REDING underscored, we are, unquestionably, at a watershed moment for European Private Law:

"The optional Common European Sales Law will help kick-start the Single Market...It will provide firms with an easy and cheap way to expand their business to new markets in Europe while giving consumers better deals and a high level of protection...Instead of setting aside national laws, today the European Commission is taking

${ }^{143}$ Above (note 127). 
an innovative approach based on free choice, subsidiarity and competition." 144

Indeed, given the structure of the proposed optional instrument, it may be the harbinger of a European Contract Law. Yet, as the proposed optional instrument moves through the legislative process, caution needs to be urged as there are a number of issues and challenges for any optional instrument, some of which may be incapable of solution solely through legislative intervention. Moreover, the debate on the broader, Private International Law implications of the (proposed) Common European Sales Law has yet to be fully developed. Nonetheless it is clear that the increased choice of law brought about by the emergent framework comes at a price and means that traders outside the EU will need to conduct additional risk assessments of their contractual practice.

${ }^{144}$ Commissioner REDING in Press Release IP/11/1175. 